Research Article

\title{
Experiment on Mine Ground Pressure of Stiff Coal-Pillar Entry Retaining under the Activation Condition of Hard Roof
}

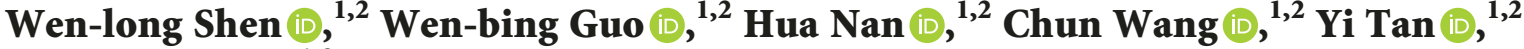 \\ and Fa-qiang $\mathrm{Su}^{1,2}$ \\ ${ }^{1}$ School of Energy Science and Engineering, Henan Polytechnic University, Jiaozuo 454000, China \\ ${ }^{2}$ Collaborative Innovation Center of Coal Work Safety of Henan Province, Jiaozuo 454000, China
}

Correspondence should be addressed to Wen-bing Guo; guowb@hpu.edu.cn; Hua Nan; nanhua@hpu.edu.cn; Chun Wang; wangchun@hpu.edu.cn, and Yi Tan; 517237667@qq.com

Received 9 May 2018; Revised 10 July 2018; Accepted 14 August 2018; Published 18 October 2018

Academic Editor: Mohsen S. Masoudian

Copyright (c) 2018 Wen-long Shen et al. This is an open access article distributed under the Creative Commons Attribution License, which permits unrestricted use, distribution, and reproduction in any medium, provided the original work is properly cited.

In mining excavation, the retained entry with stiff coal pillar is situated in the strong mine ground pressure. Influenced by mining abutment stress and dynamic stress (the vibration signal) induced from the hard roof activation, the retained entry may be subjected to roof separation, supporting body failure, severe floor heave, and even roof collapse. Based on a 2D physical model, an experimental method with plane-stress conditions was used to simulate the mechanical behavior of the rock strata during mining. In this experiment, three monitoring systems were adopted to reveal the characteristics of the strong mine ground pressure in the stiff coal-pillar entry retaining. The results show that the hard roof undergoes bending down, fracture, and caving activation successively until it is able to support overlying loads. The abutment stress which is induced from the loading transfer in stiff coal pillar is larger than that in other rocks around the retained entry in amplification, and overlying loads above the worked-out area have a loading effect on the unworked-out area. When the hard roof is situated in the activation state, the dynamic stress is generated from the hard roof activation, which is verified by the great saltation of acoustic emission signals. The results of mining ground pressure in the physical model can clearly illustrate the mechanical behavior of the rock around the retained entry with stiff coal pillar.

\section{Introduction}

As a fossil energy source, coal has provided enormous energy for human civilization in the past and in the future. Strip mining and underground mining are the main ways to maintain the sustainable development of coal production. Security maintenance of entries in underground mining requires solving many engineering and mechanical problems, which is a key technology to ensure the normal operation of the production system [1]. As the development of the longwall mining, there are two entries on both sides of every longwall panel, which is called the two-entry system throughout the world [2-4]. Figure 1 schematically shows the two-entry system when extracting coal from Panel 1. Head entry 1 and Tail entry 2 serve Panel 1 together with auxiliary transportation and ventilation function until the coal is mined out in Panel 1. However, Tail entry 2 faces a number of challenges which are caused by extraction, such as mining-induced stress evolution, instability of support body, roof separation, and the severe floor heave. From the view of mechanics, the question that whether Tail entry 2 can be retained to serve Panel 2 with stiff coal pillar needs to be further discussed.

Stage 1 is the in situ stress state of Tail entry 2, which is not affected by the hard roof activation above the adjacent gob; Stage 2 is the stress evolution state of Tail entry 2, which is affected by the hard roof activation above the adjacent gob; Stage 3 is the side abutment stress state of Tail entry 2, which is not affected by the hard roof activation above the adjacent gob; and Tail entry 2 should be retained to serve Panel 2. 


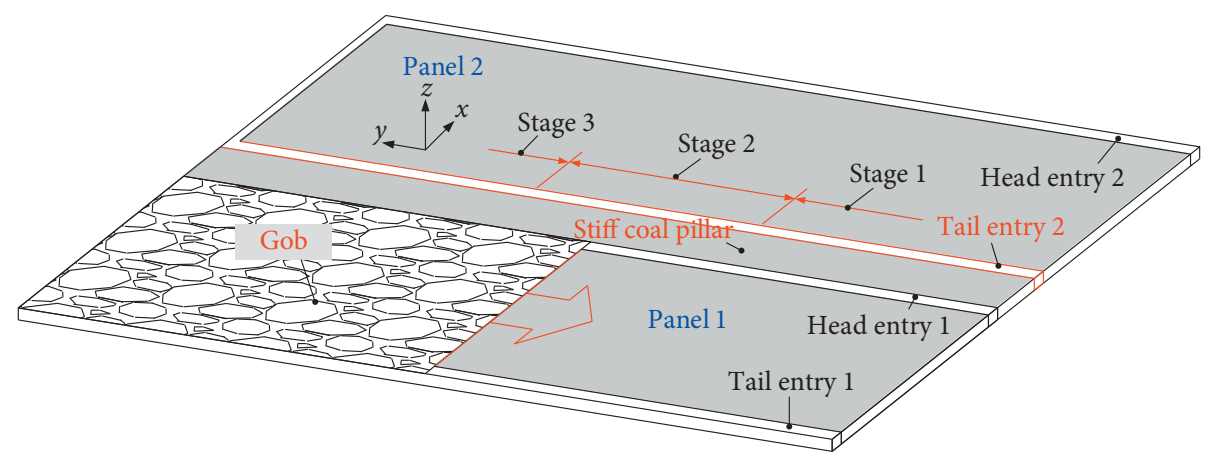

FIgURE 1: Layout of two-entry system in longwall panel.

Coal pillar width determines the stress condition around the retained entry during the hard roof activation above the gob in Panel 1 [5-9]. Strength reduction of the coal pillar is treated as the decreasing ratio of the pillar's width and height [10]. When the hard roof above the gob is stable in Panel 1, yield coal pillar places the retained entry in the stress-releasing state, while stiff coal pillar places it in the stress concentration state [11]. Shabanimashcool and Li [12] found that stresses in the stiff coal pillar fluctuate up and down during mining because of periodic cave-in events behind the longwall face. Wang et al. [13] believed that the coal bump risk of the retained entry is enhanced significantly when the coal pillar width increases. Bai et al. [14] analyzed the roof failure mechanism of the retained entry and determined the width of the coal pillar as less than $5 \mathrm{~m}$ or more than $22 \mathrm{~m}$ based on the side abutment stress evolution. Under the condition of the field monitoring, $\mathrm{Yu}$ et al. [15] found that the mininginduced abutment stress in $38 \mathrm{~m}$ wide stiff coal pillar is affected by the hard roof activation above the gob with the increase of $21 \mathrm{MPa}$, while the consideration of the mininginduced dynamic stress in the stiff coal pillar was not involved. Mohammadi et al. [16] demonstrated that the extension of excavation-damaged zone above the retained entry occurs as the coal pillar width decreases from $30 \mathrm{~m}$ to $10 \mathrm{~m}$ based on a computational geometric model. Shen et al. [17] concluded that the roof with weak plane for the retained entry is easily subjected to shear failure when the ratio of the pillar's width and height is less than $8 \mathrm{~m}$. Several significant researches have great influence on the stability of the retained entry [18-22].

The method of cutting hard roof to achieve the pressure relief has been widely used in the world [23-25]. Huang et al. [26] proposed a method of improving the top coal cavability through top coal and roof hydraulic fracturing, which makes the recovery ratio reaches more than $80 \%$ under the condition of hard super-thick coal seam. Through the physical experiment of the hydraulic fracturing for hard roof, Lin et al. [27] obtained that the initial notch can effectively reduce breakdown pressure, and a longer notch together with an appropriate notch angle can result in a more gradual, smoother fracture reorientation path in the hard roof. Han et al. [28] determined the optimal cantilever length of the lateral cantilever roof structure according to the deformation of the retained entry. As the development of the hydraulic fracturing technology, the hard roof weakening not only improves the cavability but also decreases the abutment stress around the worked-out area during longwall mining [29]. Bai et al. [30] demonstrated that hard roof treatment results in the lower stress concentration and smaller deformation, making it possible for safe retained entry by using small pillar sizes based on the numerical simulation results. Besides, Xia et al. [31-33] discussed the mininginduced ground movement and deformation in tectonic stress metal mines based on case studies.

In this work, a $2 \mathrm{D}$ physical model with plane-stress conditions was established to simulate the mechanical behavior of the rock strata behind the working face during the mining process. In this physical model, three monitoring systems were used to reveal the characteristics of strong mine ground pressure in stiff coal-pillar entry retaining.

\section{Experimental Method}

2.1. Geological and Mining Conditions. First Yangquan coal mine is located in the city of Yangquan, Shanxi Province, China. The two-entry system, which is employed in the longwall top coal caving operation, is approximately $2200 \mathrm{~m}$ long by $220 \mathrm{~m}$ wide in every panel as shown in Figure 1. The average thickness and buried depth of coal seam 15 are $6.5 \mathrm{~m}$ and $600 \mathrm{~m}$ with the dip angle of $4^{\circ}$. As shown in Figure 2, the rock strata above coal seam 15 are limestone, mudstone group, and fine sandstone, whereas rock strata below coal seam 15 are mudstone and sandstone. The south of Panel 2 is Panel 1, the retreating area. The north of Panel 2 is Panel 3, which does not have any mining activities. The east of Panel 2 is the mine boundary, and there are three entries in the west of Panel 2. The Tail entry 2 with dimensions of $5.0 \mathrm{~m} \times$ $4.0 \mathrm{~m}$ is arranged along the immediate roof. The width of the stiff coal pillar is $15 \mathrm{~m}$.

2.2. Physical Model. The physical experiment was conducted by a physical modeling system at the State Key Laboratory of Coal Resources and Mine Safety in China. As shown in Figure 3, the modeling system consists of a servo load 


\begin{tabular}{|c|c|c|c|}
\hline Lithology & $\begin{array}{l}\text { Thickness } \\
\text { (m) }\end{array}$ & $\begin{array}{l}\text { Depth } \\
\text { (m) }\end{array}$ & Remarks \\
\hline Mudstone & 10.0 & 469.0 & Mudstone \\
\hline Medium sandstone & 23.0 & 479.0 & Hard roof \\
\hline Siltstone & 5.0 & 484.0 & \multirow{5}{*}{ Mudstone group } \\
\hline Sandy mudstone & 10.0 & 494.0 & \\
\hline Silty mudstone & 5.0 & 499.0 & \\
\hline Mudstone & 10.0 & 509.0 & \\
\hline Sandy mudstone & 20.0 & 529.0 & \\
\hline Fine sandstone & 18.0 & 547.0 & Hard roof \\
\hline Sandy mudstone & 10.0 & 557.0 & \multirow{5}{*}{ Mudstone group } \\
\hline Siltstone & 2.0 & 559.0 & \\
\hline Mudstone & 8.0 & 567.0 & \\
\hline Sandy mudstone & 2.0 & 569.0 & \\
\hline Mudstone & 11.0 & 580.0 & \\
\hline Limestone & 13.5 & 593.5 & Hard roof \\
\hline Coal seam 15 & 6.5 & 600.0 & Coal seam \\
\hline Mudstone & 2.0 & 602.0 & Mudstone \\
\hline
\end{tabular}

Figure 2: Generalized stratigraphic column.

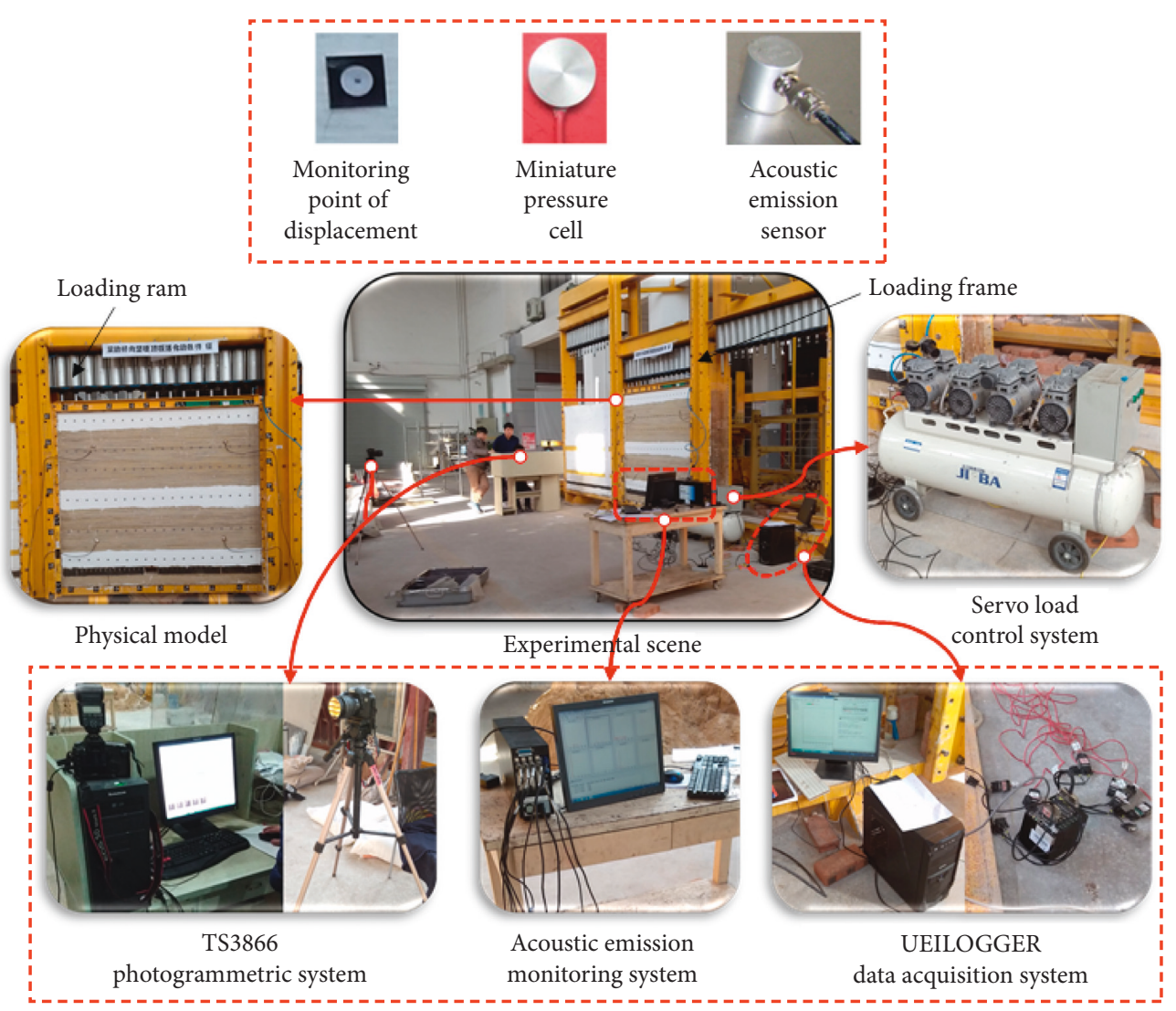

FIGURE 3: Experimental scene with physical model and monitoring systems.

control system, a high stiff loading frame, and three monitoring systems. The dimension of the physical model reaches $2.5 \mathrm{~m}$ in length, $0.3 \mathrm{~m}$ in width, and $2 \mathrm{~m}$ in height. Under the geological and engineering condition of the retained entry in Panel 2 of First Yangquan coal mine, the rock strata of $400 \mathrm{~m}$ long in the field were established to simulate the mechanical behavior in Panel 1 of $220 \mathrm{~m}$ long, the stiff coal pillar of $15 \mathrm{~m}$ long, the retained entry of $5 \mathrm{~m}$ long, partial Panel 2 of $80 \mathrm{~m}$ long, and the boundary of $80 \mathrm{~m}$ long in the physical model. According to the similarity theory [34], strength, density, and geometry should follow the particular relationship as Equation (1). For this work, similarity ratios of $C_{L}, C_{\rho}, C_{\sigma}, C_{t}$ are determined as $160,1.53$, 244.8 , and 12.65 , respectively. 


$$
\left\{\begin{array}{l}
\frac{C_{\sigma}}{C_{\rho} C_{L}}=1, \\
C_{L}=\frac{L_{\mathrm{p}}}{L_{\mathrm{m}}}, \\
C_{\sigma}=\frac{\sigma_{\mathrm{p}}}{\sigma_{\mathrm{m}}}, \\
C_{\rho}=\frac{\rho_{\mathrm{p}}}{\rho_{\mathrm{m}}}, \\
C_{t}=\frac{C_{L}}{\sqrt{C_{L}}},
\end{array}\right.
$$

where $C_{L}, C_{\sigma}$, and $C_{t}$ are the similarity ratios of geometry, strength, and time, respectively. $C_{\rho}$ is the density similarity ratio between the prototype and the model. $L_{\mathrm{p}}, \sigma_{\mathrm{p}}$, and $\rho_{\mathrm{p}}$ represent the dimension, strength, and density of the rock strata in the field; $L_{\mathrm{m}}, \sigma_{\mathrm{m}}$, and $\rho_{\mathrm{m}}$ represent the dimension, strength, and density of the rock strata in the model.

2.3. Physical Materials. As shown in Figure 2, eight materials with different deformability and strength are used to simulate the mechanical behavior of the rock strata, including mudstone, coal seam 15, limestone, mudstone group 1, fine sandstone, mudstone group 2, medium sandstone, and mudstone group 3. Physical materials are mingled with sand, gypsum, calcium carbonate, water, and mica powder. Under the condition of the uniaxial compression test and the strength similarity ratio, the ratio of the material contents is determined based on the existing results [35]. For this work, eight materials are presented in Table 1 . Totally, $1733.91 \mathrm{~kg}$ sand, $169.10 \mathrm{~kg}$ calcium carbonate, $234.49 \mathrm{~kg}$ gypsum, and $25 \mathrm{~kg}$ mica powder are deserved in this model.

2.4. Monitoring Instruments and Methods. Evolution of the abutment stress, acoustic emission signals, and the rock strata displacement are determined as indexes of the mine ground pressure during the hard roof activation above the gob. UEILOGGER 3.0.0 data acquisition system, made by American UEL Company, was used to monitor the evolution of the abutment stress. The system consists of four parts, including the miniature pressure cell, UEILOGGER host, data transmission cable, and data processing software. The miniature pressure cell is capable of operating in the saturated aqueous medium. The measurement range of the miniature pressure cell is $0.02-1.5 \mathrm{MPa}$, the deviation is limited to $0.5 \% \mathrm{FS}$, and acquisition frequency is set at $1 \mathrm{~Hz}$ in this monitoring programme. The acoustic emission monitoring system (AEwin), made by American Physical Acoustics Corporation, was used to monitor acoustic emission signals. This system also consists of four parts, including the acoustic emission sensor, the acoustic emission host, the data transmission cable, and data processing software. The measurement range is $1 \mathrm{kHz}-3 \mathrm{MHz}$ vibration frequency, and maximum acquisition frequency reaches $40 \mathrm{MHz}$ for the acoustic emission monitoring system. The resonant frequency, the sensitivity peak, and the effective acquisition frequency of the acoustic emission sensor are $40 \mathrm{kHz}, 75 \mathrm{~dB}$, and $15 \mathrm{kHz}-70 \mathrm{kHz}$ in this monitoring programme, respectively. In addition, TS3866 digital photogrammetry system was used to monitor the rock strata displacement.

Figure 4 shows the layout of monitoring points for three monitoring systems. Six miniature pressure cells $\left(P_{1}\right.$ to $P_{6}$ in Figure 4$)$, eight acoustic emission sensors $\left(S_{1}\right.$ to $S_{8}$ in Figure 4), and 144 monitoring points of displacement (Measuring line 1 to Measuring line 6 in Figure 4) are arranged in this physical model. Three miniature pressure cells are used to record the abutment stress evolution in the coal floor, and three other miniature pressure cells are used to record the abutment stress evolution around the retained entry. Two of the acoustic emission sensors are used to record acoustic emission signals in the roof of the retained entry. All the six measuring lines are used to monitor the rock movement of different rock strata in the roof. The detailed parameters of the monitoring points' layout are presented in Figure 4.

2.5. Physical Test Procedures. The whole test involves six steps: (1) Preparation of experimental tools, such as the high stiff loading frame, physical materials, mixing barrel with electric power, electronic scale, three monitoring systems, and other essential tools. (2) Model and compact the eight physical rock strata one by one, and separate every rock strata with certain mica powder. (3) Apply the vertical load $0.056 \mathrm{MPa}$ through 20 loading rams in the top frame to simulate the overburden loads, fix the normal displacement in the floor boundary, two-side boundaries with the frame, and keep the free state for the front and back boundary of the model after two months of the model completion. (4) Conduct the excavation of the retained entry. From the view of mechanics, the additional stress around the retained entry generally comes from the activation of the hard roof structure near the retained entry, while the collapsed hard roof structure in the gob center is independent of the additional stress around the retained entry. (5) Perform the longwall successively which retreats from the panel center to panel boundary to simulate the activation effect for the hard roof of the retained entry. In each stage, $50 \mathrm{~mm}$-long coal is excavated by using a mini shovel. Then wait 20 minutes before the next excavation. During the excavation, three monitoring systems should be operated in a normal state for recording until the test procedure ends. (6) Apply additional vertical loading $200 \mathrm{~Pa}$ per second through the 20 loading rams, so as to simulate the abutment stress induced from the retreating of Panel 2. According to the existing monitoring data in the field, the additional vertical stress in the rock in the front of the working face increased by 17.29 MPa in 24 hours. So the increasing rate can be calculated approximately as the $200 \mathrm{~Pa}$ per second. 
TABLe 1: Materials used in the physical model.

\begin{tabular}{|c|c|c|c|c|c|c|c|}
\hline Lithology & $\begin{array}{c}\text { UCS of prototype } \\
(\mathrm{MPa})\end{array}$ & $\begin{array}{l}\text { UCS of model } \\
(\mathrm{kPa})\end{array}$ & Sand $(\mathrm{kg})$ & Calcium carbonate $(\mathrm{kg})$ & Gypsum (kg) & Amounts (kg) & Water $(\mathrm{L})$ \\
\hline Mudstone group 1 & 35.27 & 144.06 & 70.31 & 7.03 & 7.03 & 84.38 & 9.38 \\
\hline Medium sandstone & 70.09 & 286.30 & 158.20 & 15.82 & 36.91 & 210.94 & 23.44 \\
\hline Mudstone group 2 & 35.27 & 144.06 & 585.94 & 58.59 & 58.59 & 703.13 & 78.13 \\
\hline Fine sandstone & 74.61 & 304.81 & 189.84 & 18.98 & 44.30 & 253.13 & 36.16 \\
\hline Mudstone group 3 & 35.27 & 144.06 & 386.72 & 38.67 & 38.67 & 464.06 & 51.56 \\
\hline Limestone & 71.83 & 293.42 & 142.38 & 14.24 & 33.22 & 189.84 & 27.12 \\
\hline Coal seam 15 & 24.83 & 101.41 & 79.98 & 5.71 & 5.71 & 91.41 & 10.16 \\
\hline Mudstone & 29.71 & 121.35 & 120.54 & 10.04 & 10.04 & 140.63 & 15.63 \\
\hline
\end{tabular}

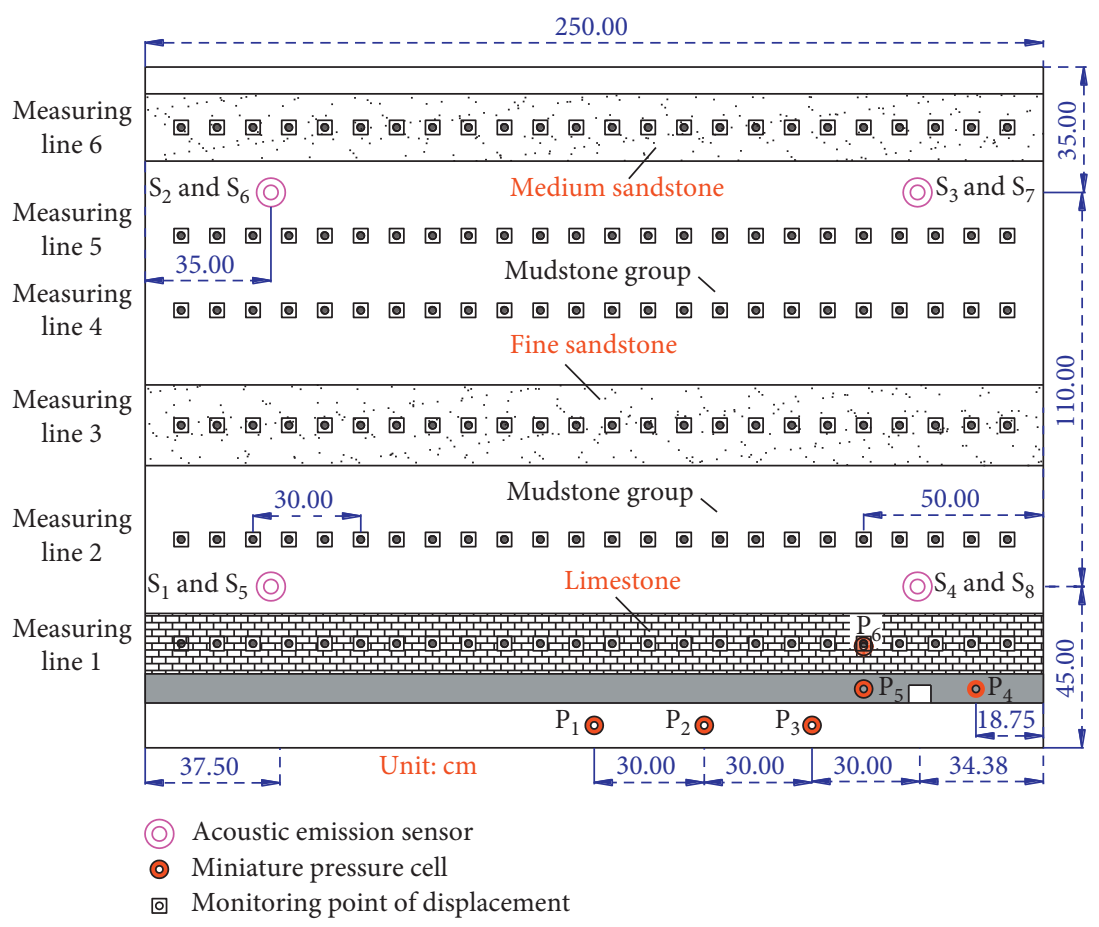

FIgURE 4: Monitoring programme in the physical model.

\section{Results}

3.1. Activation Characteristics of the Roof above the Gob. As the pictures shown in Figure 5, the suspended roof encounters bending, fracture, and caving activation when the suspended area is large enough. During the roof activation, the cantilever construction supports overburden loads behind the coal body until it occurs fracture or caving down. As shown in Figure 5(h), the cantilever construction encounters fracture above the stiff coal pillar when applying the additional vertical stress in the top physical model. As shown in Figures 5(i)-5(k), the upper hard roof, for instance, the fine sandstone which is strong enough to bear the overburden loads is called the key stratum [36], is not caving during the longwall retreating in Panel 1. However, as shown in Figure 5(1), it encounters fracture and caving activation when applying the additional vertical stress in the top physical model.

Along the vertical direction, roof bends down in the lower roof near the gob initially, and then the upper roof begins to bend down gradually. The lower roof is larger than the upper roof in vertical displacement distinctly. As the increasing distance from the gob center, the roof vertical displacement decreases gradually as the measuring data shown in Figure 6(a). When the suspended area is large enough, the roof encounters fracture activation instantaneously and then cave activation in a short time as shown in Figure 6(b). However, the soft stratum such as the mudstone group encounters fracture and cave as long as the lower hard roof like the limestone fractures and caves. As the increase of the suspended area, the roof encounters the fracture and caving activation, and the increasing caving zone compacts the gob gradually as shown from Figure 6(b) to Figure 6(e).

3.2. Evolution of the Additional Abutment Stress. At first, additional abutment stress increases slowly, then decreases sharply, and presents stabilization finally in $\mathrm{P}_{1}, \mathrm{P}_{2}$, and $\mathrm{P}_{3}$ as shown in Figures $7(\mathrm{a})-7(\mathrm{c})$. The stable value is less than zero. 


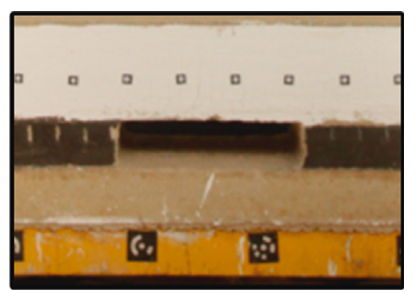

(a)

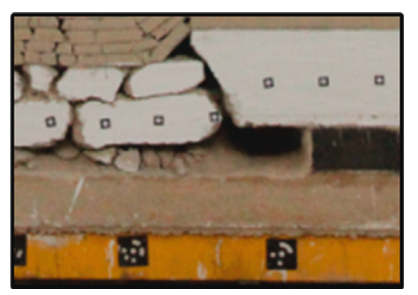

(d)

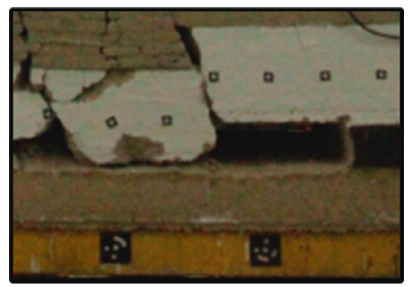

(g)

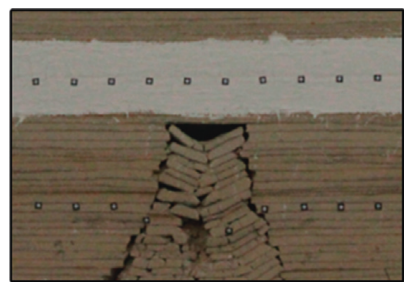

(j)

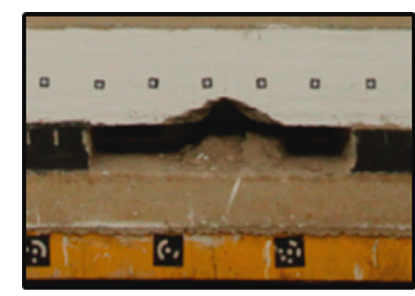

(b)

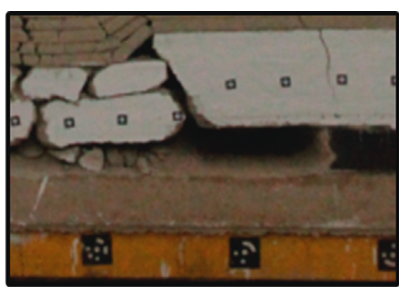

(e)

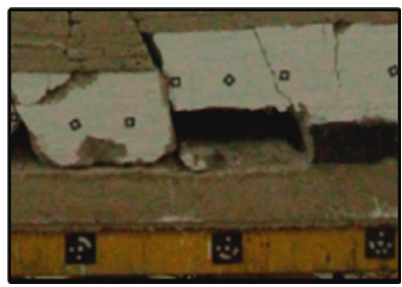

(h)

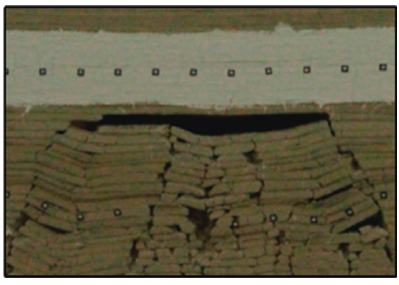

(k)

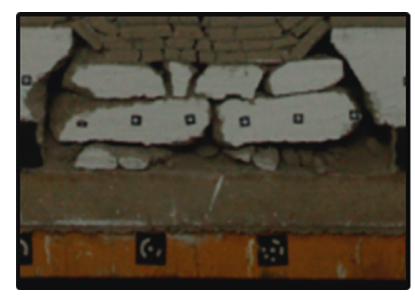

(c)

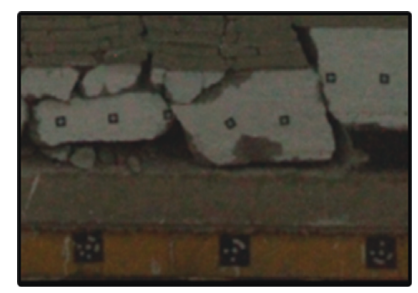

(f)

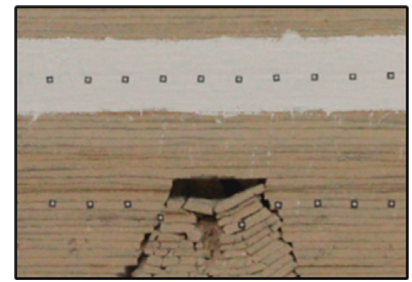

(i)

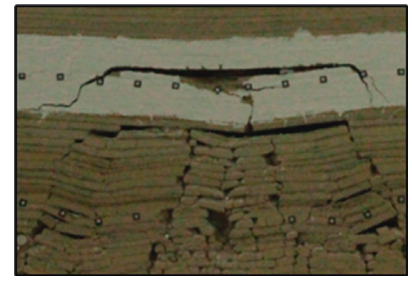

(1)

Figure 5: Roof activation characteristics. (a) Roof bending. (b) Roof fracture. (c) Roof caving. (d) Cantilever construction. (e) Cantilever construction fracture. (f) Cantilever construction caving. (g) Cantilever construction. (h) Cantilever construction fracture. (i) Upper roof condition. (j) Suspended upper roof. (k) Upper roof fracture. (l) Upper roof fracture and caving.

Besides, applying additional vertical stress in the top model is independent of the additional abutment stress in $\mathrm{P}_{1}, \mathrm{P}_{2}$, and $\mathrm{P}_{3}$. Peaks of the additional abutment stress in $\mathrm{P}_{2}$ and $\mathrm{P}_{3}$ are larger than that in $\mathrm{P}_{1}$, and the inflection point occurs when the coal is mined out above the measuring point. In addition, at first the additional abutment stress increases slowly, then increases sharply, decreases sharply afterwards, and presents stabilization in the final in $\mathrm{P}_{4}, \mathrm{P}_{5}$, and $\mathrm{P}_{6}$ as shown in Figures 7(d)-7(f). Additional abutment stress in $\mathrm{P}_{5}$ is larger than that in $\mathrm{P}_{4}$ and $\mathrm{P}_{6}$ in amplification and whose minimum is in $\mathrm{P}_{4}$. However, applying additional vertical stress in the top of the model can increase the abutment stress in $\mathrm{P}_{4}, \mathrm{P}_{5}$, and $\mathrm{P}_{6}$ greatly.

3.3. Characteristics of the Acoustic Emission Signals. Distinct acoustic emission phenomenon occurs during the hard roof activation above the gob as measuring point $S_{4}$ in Figure 8 . The ring count indicates that the number of the effective acoustic emission signals exceeds the threshold value. Obviously, the ring count turns to the saltation state instantaneously during the layered caving and cantilever construction fracture, but it always equals to zero when the roof is relatively stable as shown in Figure 8(a). The peak of the ring count occurs when applying the additional vertical stress in the top of the model. The energy, the area of the detection signal envelope, reflects the strength of the acoustic emission signal. As shown in Figure 8(b), the ring count turns to the saltation state instantaneously when layered caving and cantilever construction fracture occur, but it always equals to zero when the roof is relatively stable. When additional vertical stress is applied, the energy monitored is much greater than that in other time. In addition, the amplitude, the range of the acoustic emission wave envelope, is messy but is relatively large during the hard roof activation above the gob as shown in Figure 8(c). Similarly, it reaches the peak when applying the additional vertical stress in the top of the model. 


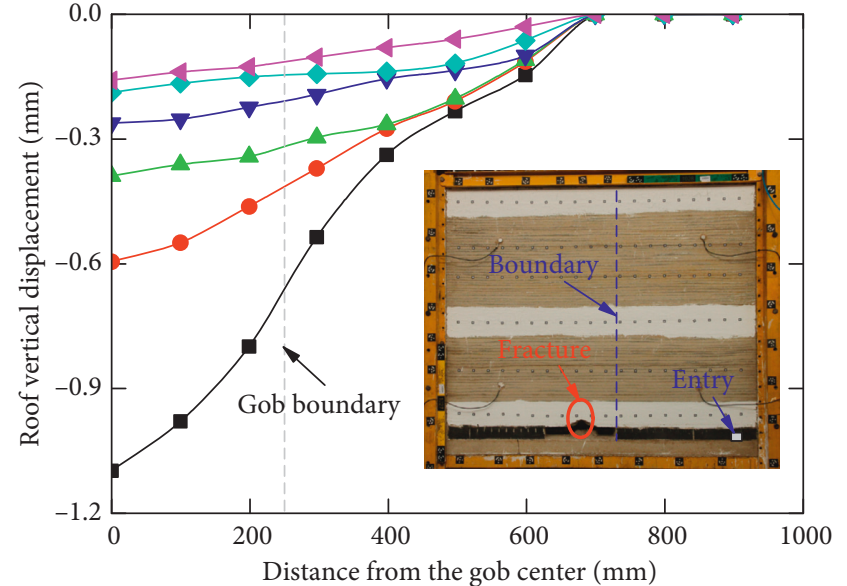

- - Measuring line 1

- Measuring line 2

— Measuring line 3

(a)

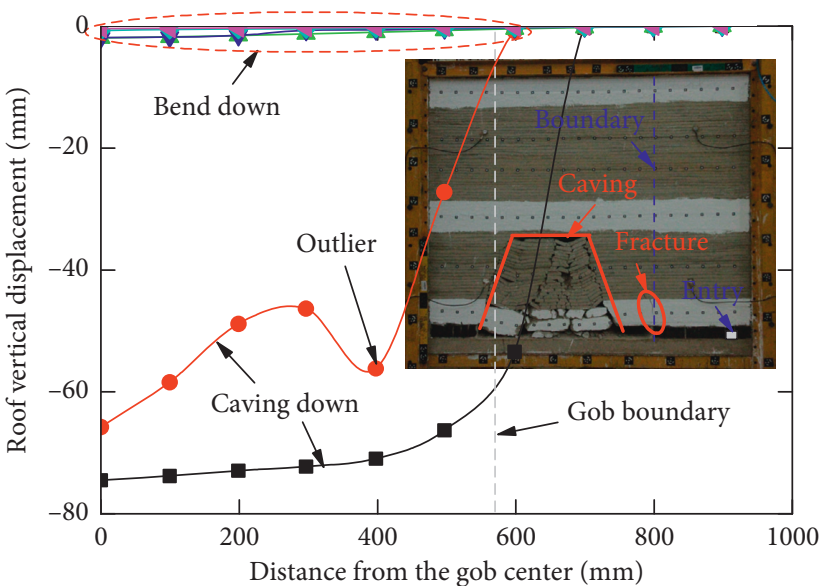

$\rightarrow$ - Measuring line 1

- Measuring line 2

- - Measuring line 3

$\rightarrow$ Measuring line 4

- Measuring line 5

$\leftarrow$ Measuring line 6

(c)

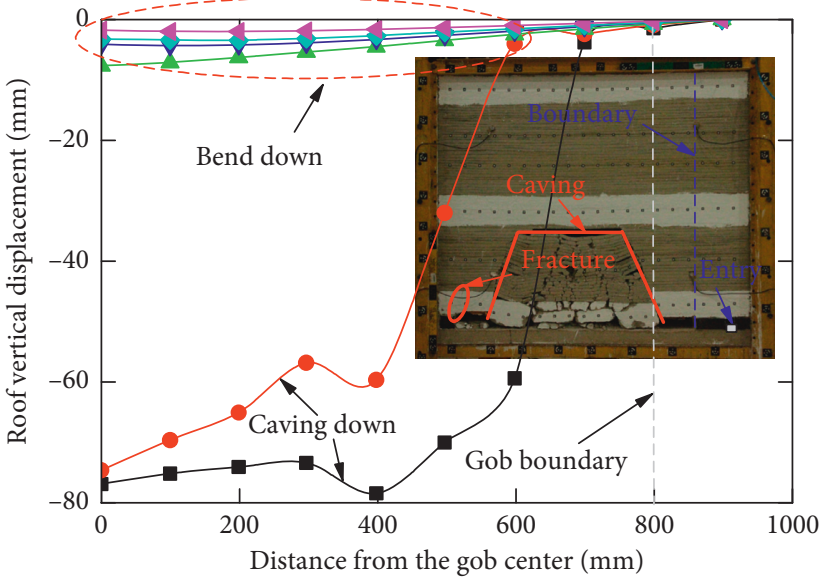

- - Measuring line 1

- Measuring line 2

- - Measuring line 3

$\rightarrow-$ Measuring line 4

- Measuring line 5

- Measuring line 6

(e)

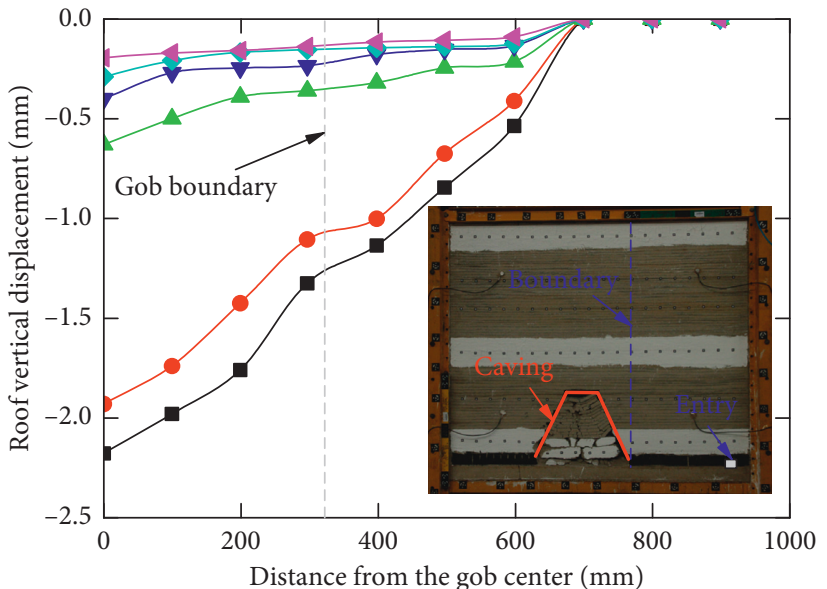

- - Measuring line 1

- - Measuring line 2

- Measuring line 3

$\neg$ Measuring line 4

_ - Measuring line 5

- Measuring line 6

(b)

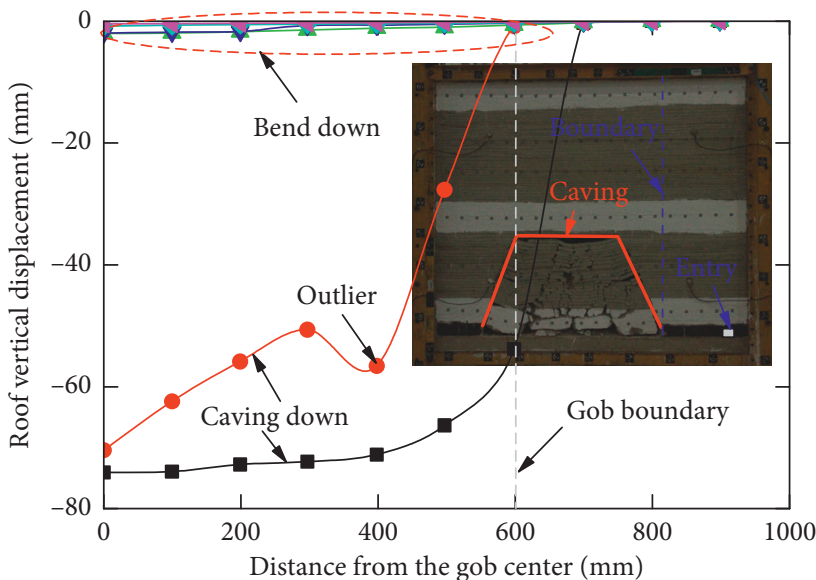

- - Measuring line 1

- Measuring line 2

- - Measuring line 3

$\neg \quad$ Measuring line 4

- Measuring line 5

- Measuring line 6

(d)

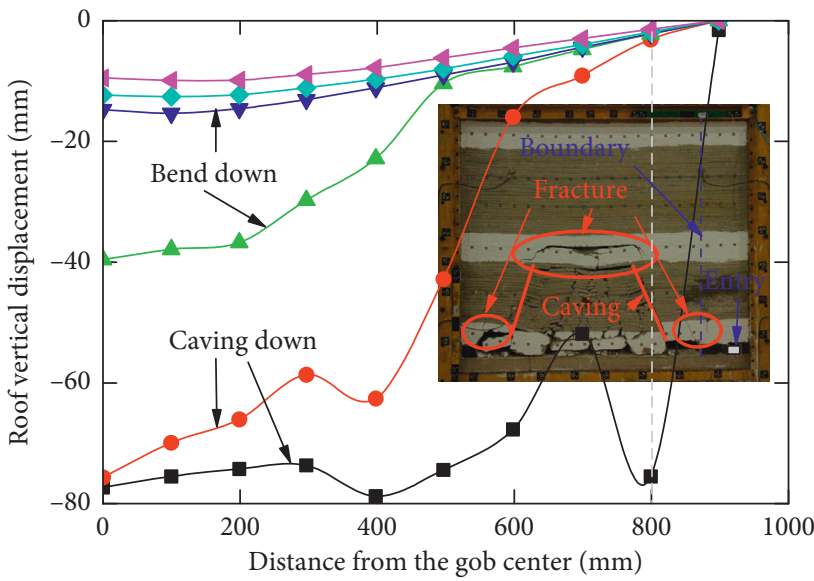

- Measuring line 1

- Measuring line 2

$\rightarrow$ Measuring line 4

$\_$Measuring line 5

- - Measuring line 3

(f)

Figure 6: Vertical displacement of the roofs above the gob. (a) Panel 1 retreating $500 \mathrm{~mm}$. (b) Panel 1 retreating $650 \mathrm{~mm}$. (c) Panel 1 retreating $1150 \mathrm{~mm}$. (d) Panel 1 retreating $1200 \mathrm{~mm}$. (e) Panel 1 retreating $1600 \mathrm{~mm}$. (f) Applying additional abutment stress. 


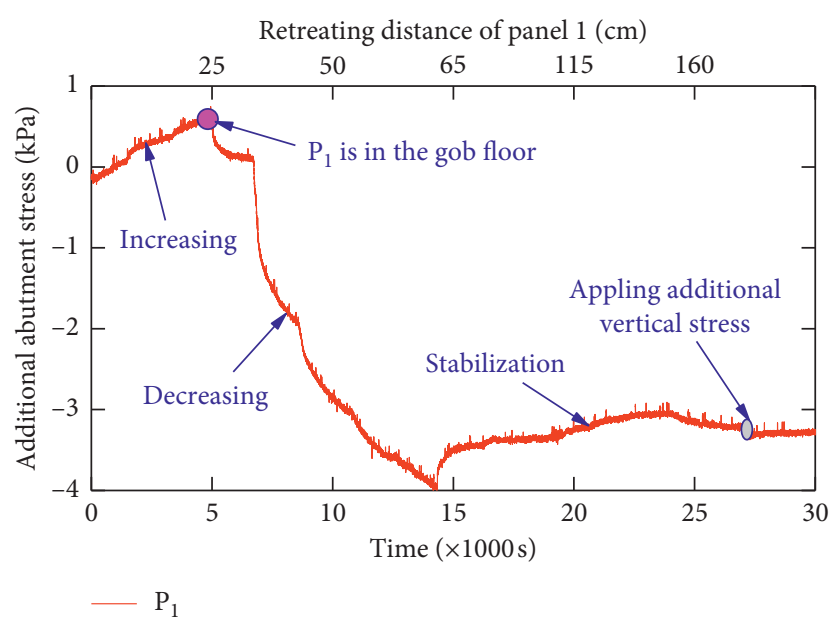

(a)

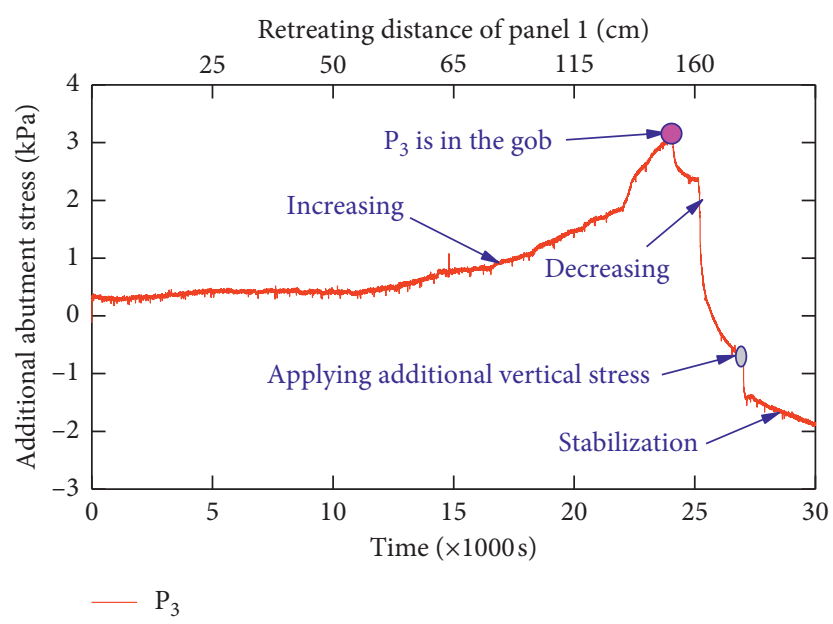

(c)

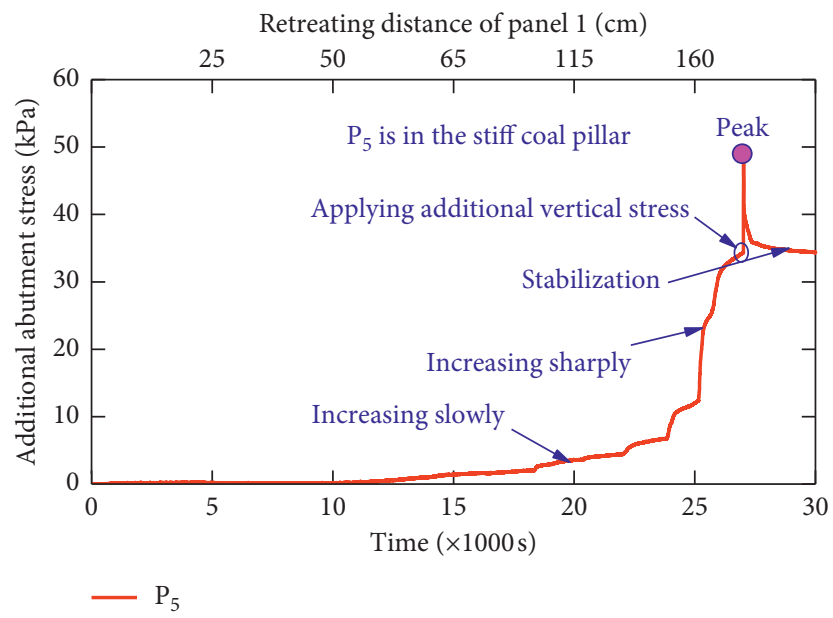

(e)

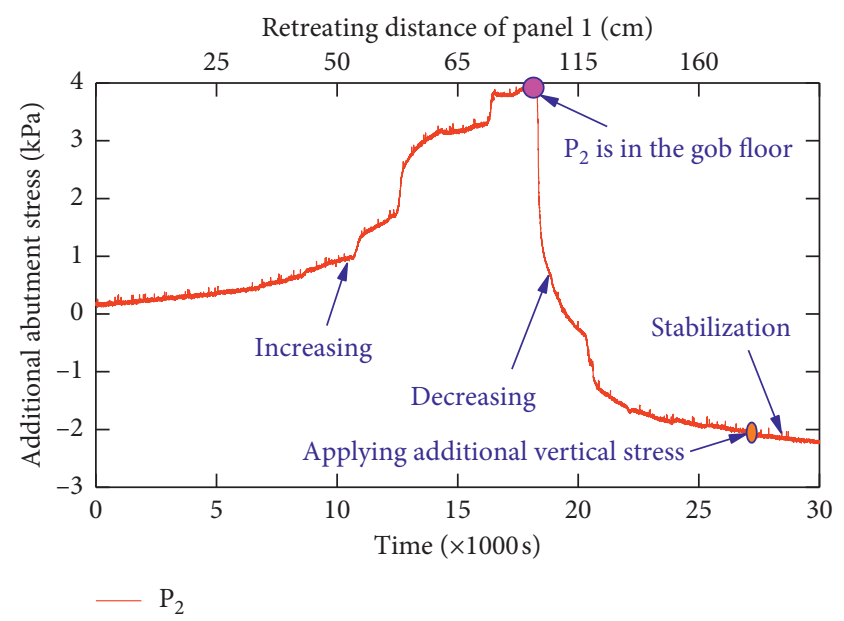

(b)

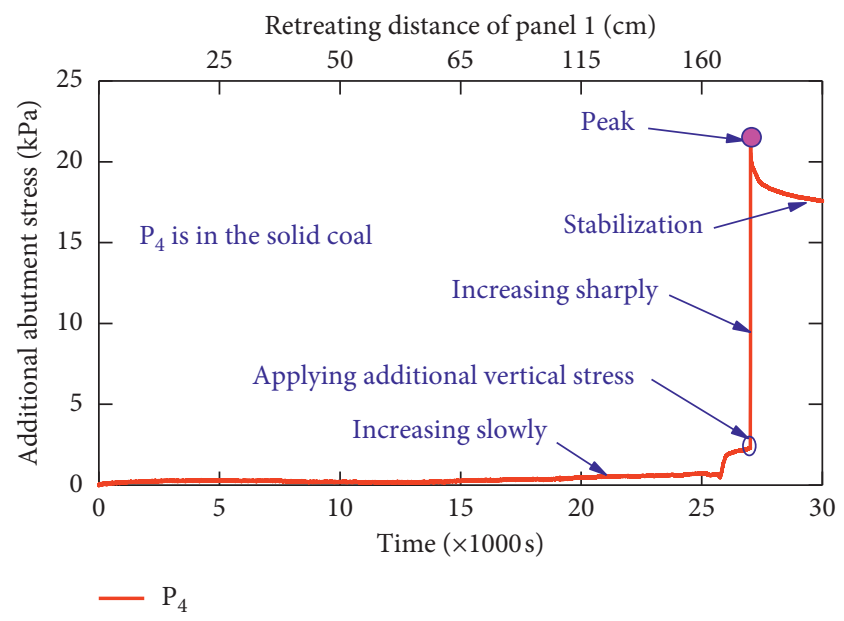

(d)

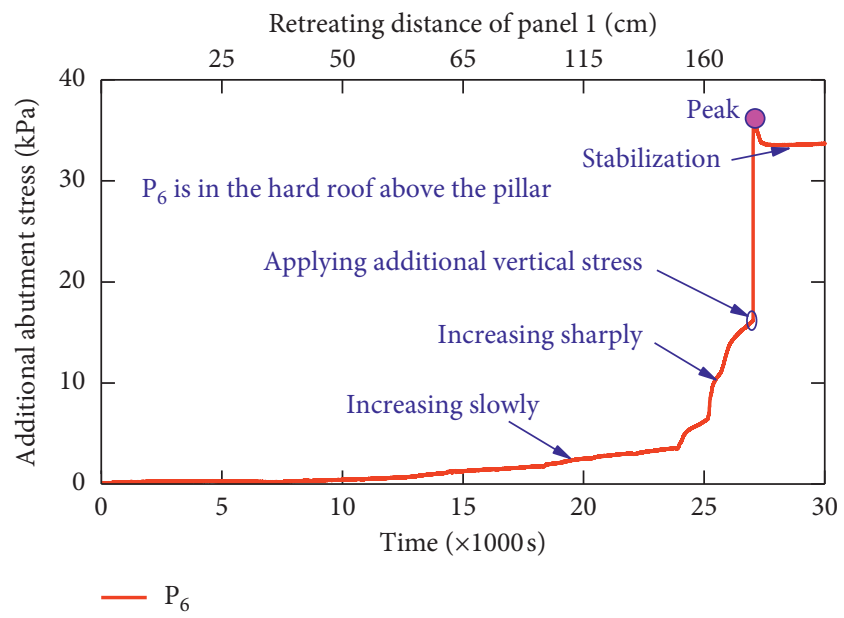

(f)

Figure 7: Additional abutment stress evolution during the hard roof activation above the gob. (a) Measuring point of $\mathrm{P}_{1}$. (b) Measuring point of $\mathrm{P}_{2}$. (c) Measuring point of $\mathrm{P}_{3}$. (d) Measuring point of $\mathrm{P}_{4}$. (e) Measuring point of $\mathrm{P}_{5}$. (f) Measuring point of $\mathrm{P}_{6}$.

\section{Discussion}

In mining excavation, stiff coal-pillar entry retaining is under the condition of strong mine ground pressure, which is validated by the physical method. The rock around the retained entry experiences not only the evolution of the side abutment stress and the front abutment stress [37] but also the loading of dynamic stress induced from the fracture and 


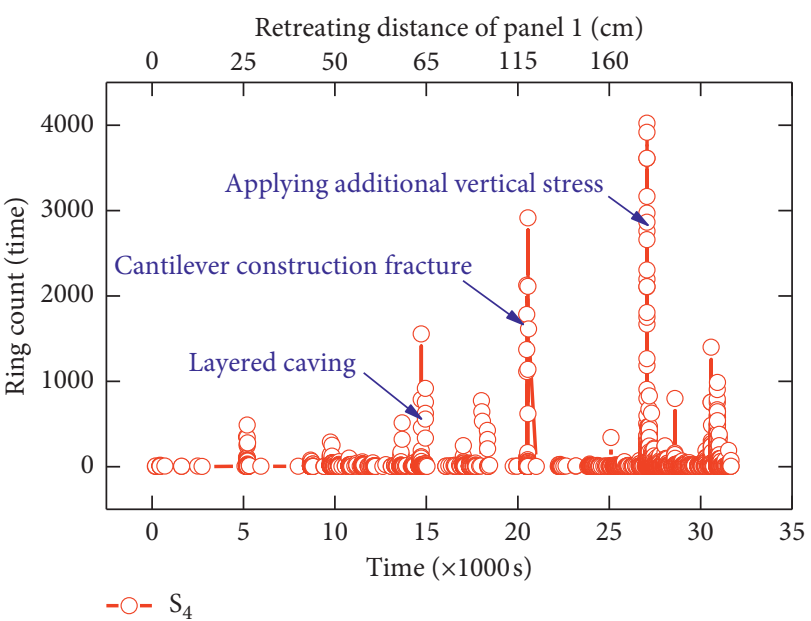

(a)

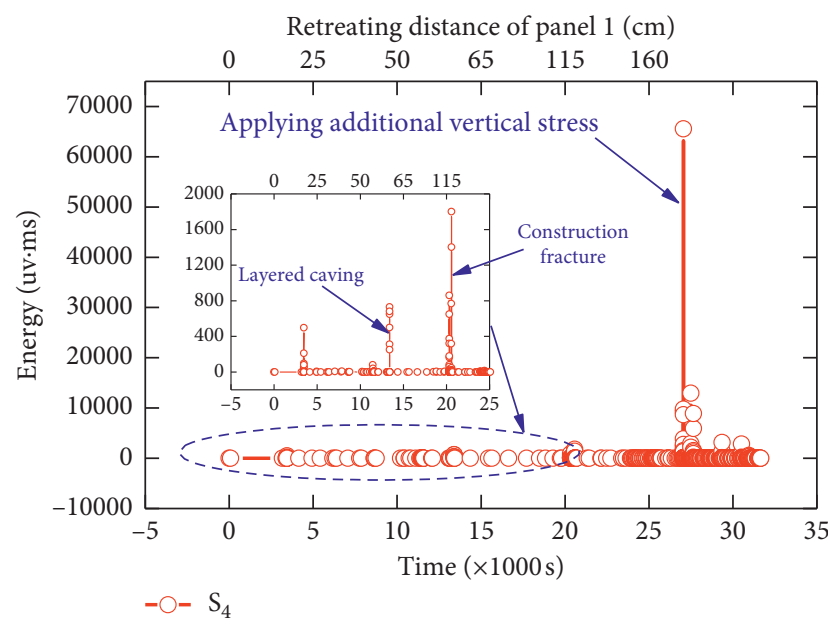

(b)

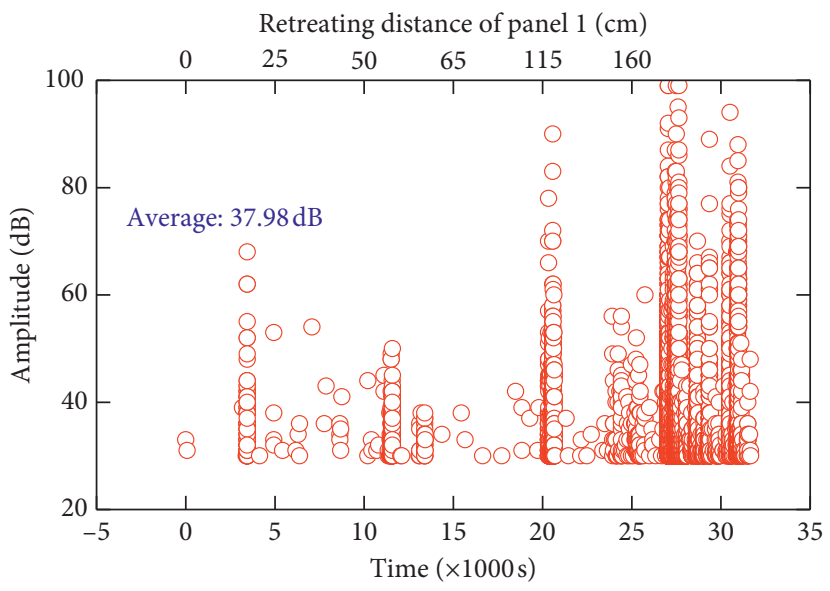

$\circ \mathrm{S}_{4}$

(c)

Figure 8: Acoustic emission signals during the activation of the hard roof above the gob. (a) Ring count in measuring point $S_{4}$. (b) Energies in measuring point $S_{4}$. (c) Amplitude in measuring point $S_{4}$.
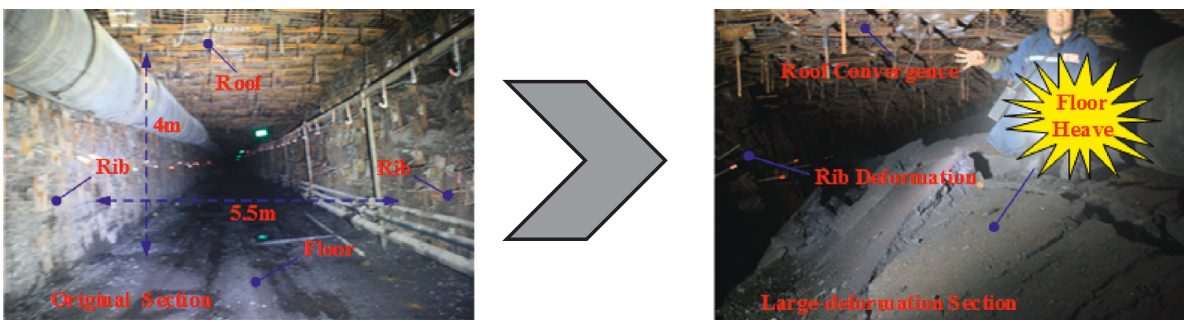

FIGURE 9: Deformation characteristics of the $19.5 \mathrm{~m}$ stiff coal-pillar entry retaining [39]. The entry experiences the whole hard roof activation above the gob.

caving activation for the hard roof. When the strength and the stiffness are insufficient to support the overburden loads, the hard roof structure experiences fracture and caving activation like the limestone shown in Figure 5. The cumulative energy of elastic deformation in the structure may release the dynamic stress instantaneously [38]. When the dynamic stress waves to the underground space like the retained entry, dynamic disasters such as the large deformation in short time occur, even if the retained entry is protected with a stiff coal pillar, such as deformation results of the retained entry shown in Figure 9.

The suspended roof encounters bending, fracture, and caving activation when the suspended area is large enough. During the activation process, overlying loads above the worked-out area have a loading effect on the unworked-out area. Besides, the generating dynamic 
stress wave to the nearby retained entry, which makes the rock around the retained entry under the synergy effect of abutment stress and dynamic stress. The results of mining ground pressure in the physical model of plane stress can clearly illustrate the mechanical behavior of the rock around the retained entry with stiff coal pillar under the hard roof [40].

However, the physical model can only simulate the mechanical behavior of the rock strata behind the working face during the mining process when it is under the planestress condition. When there are several hard roofs near the mining coal seam, this experimental method is a great option for predicting the mine ground pressure of the stiff coal-pillar entry retaining, while it is inappropriate for predicting the deformation behavior of the retained entry when the dimension of the entry is just $31 \mathrm{~mm}$ in width and $25 \mathrm{~mm}$ in height. In addition, when monitoring the dynamic stress induced from the hard roof activation, the monitoring system of high-frequency pressure cell is more convinced than vibration signals with the acoustic emission.

\section{Conclusions}

In order to reveal the mine ground pressure of stiff coalpillar entry retaining and verify whether this entry can be retained to serve the next panel influenced by the hard roof activation, a 2D physical model with plane-stress conditions was established to simulate the mechanical behavior of hard roofs behind the working face. The results of the experimental method are concluded as follows.

(1) The hard roof closed to the gob undergoes bending down, fracture, and caving activation successively unless its upper hard roof is strong enough to support overlying loads. The cantilever structure, which is supported by the stiff coal pillar above the gob, faces the potential fracture activation above the stiff coal pillar under the front abutment stress induced from the retreating of the next panel.

(2) Under the synergistic effects of the side varying abutment stress and dynamic stress, the entry cannot be retained to serve next panel successfully even though it is protected with a stiff coal pillar. Overlying loads above the worked-out area mainly have a loading effect in the stiff coal pillar. Besides, the dynamic stress induced from the hard roof activation can wave to the underneath retained entry.

(3) The experimental method can be used to analyze the mechanical behavior of the rock strata during the mining process. Since the geological and engineering conditions are different, the procedure is still necessary for other cases.

\section{Data Availability}

The data used to support the findings of this study are available from the corresponding author upon request.

\section{Conflicts of Interest}

The authors declare that they have no conflicts of interest.

\section{Acknowledgments}

This work was supported by the National Natural Science Foundation of China (contract nos. 51804099, 51774111, and 51704098), the Key Scientific Research Project Fund of Colleges and Universities of Henan Province (19A440011 and 19A130001), the Natural Science Foundation of Henan Polytechnic University (B2018-4 and B2018-65), and the Regional Collaborative Innovation Project of the Xinjiang Uygur Autonomous Region (2017E0292).

\section{References}

[1] P. K. Mandal, R. Singh, J. Maiti, A. K. Singh, R. Kumar, and A. Sinha, "Underpinning-based simultaneous extraction of contiguous sections of a thick coal seam under weak and laminated parting," International Journal of Rock Mechanics and Mining Sciences, vol. 45, no. 1, pp. 11-28, 2008.

[2] M. Colwell, D. Hill, and R. Frith, "ALTS II: a longwall gateroad design methodology for Australian collieries," in Proceedings of the First Australasian Ground Control in Mining Conference, Sydney, NSW, Australia, August 2003.

[3] M. Shabanimashcool and C. C. Li, "Numerical modelling of longwall mining and stability analysis of the gates in a coal mine," International Journal of Rock Mechanics and Mining Sciences, vol. 51, pp. 24-34, 2012.

[4] Y. Chen, S. Q. Ma, and Y. Yu, "Stability control of underground roadways subjected to stresses caused by extraction of a 10-m-thick coal seam: a case study," Rock Mechanics and Rock Engineering, vol. 50, no. 9, pp. 1-10, 2017.

[5] M. Colwell, R. Frith, and C. Mark, "Analysis of longwall tailgate serviceability (ALTS): a chain pillar design methodology for Australian conditions," in Proceedings of the Second International Workshop on Coal Pillar Mechanics and Design, pp. 33-48, 1999.

[6] J. B. Bai and C. J. Hou, "Numerical simulation study on stability of narrow coal pillar of roadway driving along goaf," Chinese Journal of Rock Mechanics and Engineering, vol. 23, no. 20, pp. 3475-3479, 2004.

[7] E. Jiránková, V. Petroš, and J. Šancer, "The assessment of stress in an exploited rock mass based on the disturbance of the rigid overlying strata," International Journal of Rock Mechanics and Mining Sciences, vol. 50, pp. 77-82, 2012.

[8] G. Zhang, Y. Tan, S. Liang, and H. Jia, "Numerical estimation of suitable gob-side filling wall width in a highly gassy longwall mining panel," International Journal of Geomechanics, vol. 18, no. 8, article 04018091, 2018.

[9] G. Zhang, S. Liang, Y. Tan, F. X. Xie, S. Chen, and H. Jia, "Numerical modeling for longwall pillar design: a case study from a typical longwall panel in China," Journal of Geophysics and Engineering, vol. 15, no. 1, pp. 121-134, 2018.

[10] E. Esterhuizen, C. Mark, and M. M. Murphy, "Numerical model calibration for simulating coal pillars, gob and overburden response," in Proceedings of the Twenty-Ninth International Conference on Ground Control in Mining, pp. 46-57, Morgantown, WV, USA, July 2010.

[11] W. F. Li, J. B. Bai, S. Peng, X. Y. Wang, and Y. Xu, "Numerical modeling for yield pillar design: a case study," Rock Mechanics and Rock Engineering, vol. 48, no. 1, pp. 305-318, 2014. 
[12] M. Shabanimashcool and C. C. Li, "A numerical study of stress changes in barrier pillars and a border area in a longwall coal mine," International Journal of Coal Geology, vol. 106, pp. 39-47, 2013.

[13] H. Wang, Y. Jiang, Y. Zhao, J. Zhu, and S. Liu, "Numerical investigation of the dynamic mechanical state of a coal pillar during longwall mining panel extraction," Rock Mechanics and Rock Engineering, vol. 46, no. 5, pp. 1211-1221, 2013.

[14] J. B. Bai, W. L. Shen, G. L. Guo, X. Y. Wang, and Y. Yu, "Roof deformation, failure characteristics, and preventive techniques of gob-side entry driving heading adjacent to the advancing working face," Rock Mechanics and Rock Engineering, vol. 48, no. 6, pp. 2447-2458, 2015.

[15] B. Yu, Z. Zhang, T. Kuang, and J. Liu, "Stress changes and deformation monitoring of longwall coal pillars located in weak ground," Rock Mechanics and Rock Engineering, vol. 49, no. 8, pp. 3293-3305, 2016.

[16] H. Mohammadi, M. A. E. Farsangi, H. Jalalifar, and A. R. Ahmadi, "A geometric computational model for calculation of longwall face effect on gate roadways," Rock Mechanics and Rock Engineering, vol. 49, no. 1, pp. 303-314, 2016.

[17] W. L. Shen, J. B. Bai, W. F. Li, and X. Y. Wang, "Prediction of relative displacement for entry roof with weak plane under the effect of mining abutment stress," Tunnelling and Underground Space Technology, vol. 71, pp. 309-317, 2018.

[18] W. L. Shen, T. Q. Xiao, M. Wang, J. B. Bai, and X. Y. Wang, "Numerical modeling of entry position design: a field case," International Journal of Mining Science and Technology, 2018, In press.

[19] Z. Z. Zhang, J. B. Bai, Y. Chen, and S. Yan, "An innovative approach for gob-side entry retaining in highly gassy fullymechanized longwall top-coal caving," International Journal of Rock Mechanics \& Mining Sciences, vol. 80, pp. 1-11, 2015.

[20] L. Jiang, P. Zhang, L. Chen et al., "Numerical approach for goaf-side entry layout and yield pillar design in fractured ground conditions," Rock Mechanics and Rock Engineering, vol. 50, no. 11, pp. 3049-3071, 2017.

[21] L. Jiang, A. Sainoki, H. S. Mitri, N. Ma, H. Liu, and Z. Hao, "Influence of fracture-induced weakening on coal mine gateroad stability," International Journal of Rock Mechanics \& Mining Sciences, vol. 88, pp. 307-317, 2016.

[22] G. C. Zhang, F. L. He, Y. H. Lai, and H. G. Jia, "Ground stability of an underground gateroad with $1 \mathrm{~km}$ burial depth: a case study from Xingdong coal mine, China," Journal of Central South University, vol. 25, no. 6, pp. 1386-1398, 2018.

[23] S. H. Advani, T. S. Lee, and R. H. Dean, "Variational principles for hydraulic fracturing," Journal of Applied Mechanics, vol. 59, no. 4, pp. 819-826, 1992.

[24] A. Van As and R. G. Jeffrey, "Hydraulic fracturing as a cave inducement technique at Northparkes mines," in Proceedings of MASSMIN 2000 Conference, pp. 165-172, Brisbane, QLD, Australia, October 2000.

[25] K. Matsui, H. Shimada, and H. Z. Anzwar, "Acceleration of massive roof caving in a longwall gob using a hydraulic fracturing," in Proceedings of Fourth International Symposium on Mining Science and Technology, pp. 43-46, Beijing, China, August 1999.

[26] B. X. Huang, Y. Wang, and S. Cao, "Cavability control by hydraulic fracturing for top coal caving in hard thick coal seams," International Journal of Rock Mechanics and Mining Sciences, vol. 74, pp. 45-57, 2015.

[27] C. Lin, J. Deng, Y. Liu, Q. Yang, and H. Duan, "Experiment simulation of hydraulic fracture in colliery hard roof control,"
Journal of Petroleum Science and Engineering, vol. 138, no. 49, pp. 265-271, 2016.

[28] C. L. Han, N. Zhang, B. Y. Li, G. Y. Si, and X. G. Zheng, "Pressure relief and structure stability mechanism of hard roof for gob-side entry retaining," Journal of Central South University, vol. 22, no. 11, pp. 4445-4455, 2015.

[29] B. X. Huang, S. Chen, and X. Zhao, "Hydraulic fracturing stress transfer methods to control the strong strata behaviours in gob-side gateroads of longwall mines," Arabian Journal of Geosciences, vol. 10, no. 11, p. 236, 2017.

[30] Q. Bai, S. Tu, F. Wang, and C. Zhang, "Field and numerical investigations of gateroad system failure induced by hard roofs in a longwall top coal caving face," International Journal of Coal Geology, vol. 173, pp. 176-199, 2017.

[31] K. Xia, C. Chen, X. Liu, Z. Yuan, and F. Hua, "Ground movement mechanism in tectonic stress metal mines with steep structure planes," Journal of Central South University, vol. 24, no. 9, pp. 2092-2104, 2017.

[32] K. Xia, C. Chen, H. Fu, Y. Pan, and Y. Deng, "Mining-induced ground deformation in tectonic stress metal mines: a case study," Bulletin of Engineering Geology and the Environment, vol. 210, no. 3, pp. 212-230, 2016.

[33] K. Xia, C. Chen, X. Liu, H. Fu, Y. Pan, and Y. Deng, "Mininginduced ground movement in tectonic stress metal mines: a case study," Bulletin of Engineering Geology and the Environment, vol. 75, no. 3, pp. 1089-1115, 2016.

[34] B. Ghabraie, G. Ren, X. Zhang, and J. Smith, "Physical modelling of subsidence from sequential extraction of partially overlapping longwall panels and study of substrata movement characteristics," International Journal of Coal Geology, vol. 140, pp. 71-83, 2015.

[35] S. H. Tu, Experimental Method and Measurement Technique of Rock Control, China University of Mining and Technology Press, Xuzhou, China, 2010.

[36] M. G. Qian, P. W. Shi, and J. L. Xu, Mine Ground Pressure and Rock Control, China University of Mining and Technology Press, Xuzhou, China, 2010.

[37] Q. Yao, Z. Jian, Y. Li, Y. Tan, and Z. Jiang, "Distribution of side abutment stress in roadway subjected to dynamic pressure and its engineering application," Shock and Vibration, vol. 2015, Article ID 929836, 11 pages, 2015.

[38] Y. Hamiel, V. Lyakhovsky, and Y. Ben-Zion, "The elastic strain energy of damaged solids with applications to nonlinear deformation of crystalline rocks," Pure and Applied Geophysics, vol. 168, no. 12, pp. 2199-2210, 2011.

[39] W. L. Shen, J. B. Bai, X. Y. Wang, and Y. Yu, "Response and control technology for entry loaded by mining abutment stress of a thick hard roof," International Journal of Rock Mechanics and Mining Sciences, vol. 90, pp. 26-34, 2016.

[40] P. Wang, L. Jiang, J. Jiang, P. Zheng, and W. Li, "Strata behaviors and rock-burst-inducing mechanism under the coupling effect of a hard thick stratum and a normal fault," International Journal of Geomechanics, vol. 18, no. 2, article 04017135, 2018. 


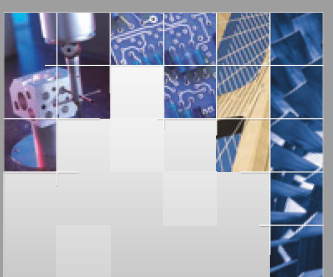

\section{Enfincering}
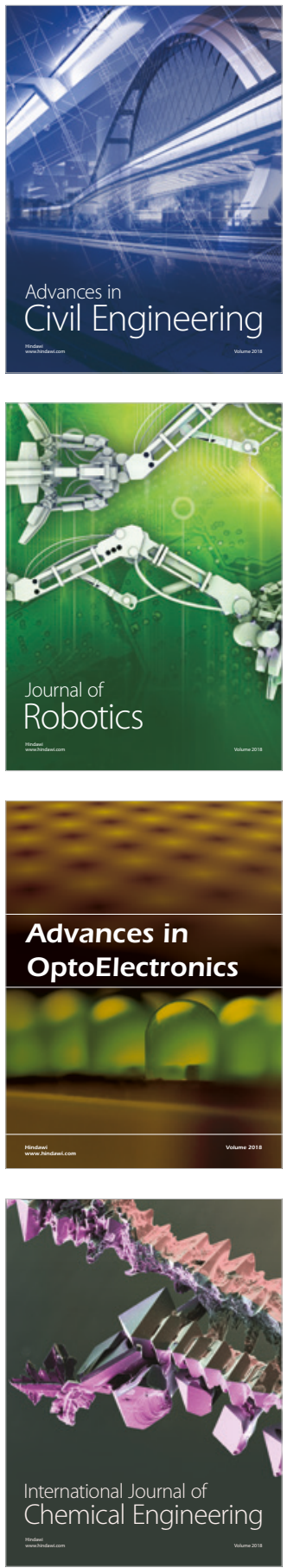

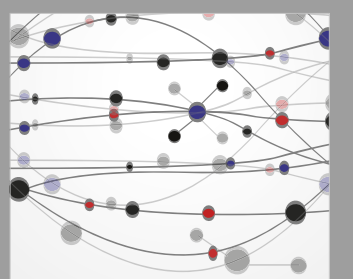

\section{Rotating \\ Machinery}

The Scientific World Journal

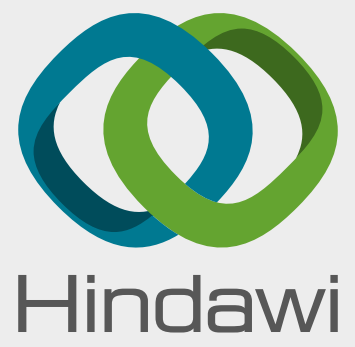

Submit your manuscripts at

www.hindawi.com
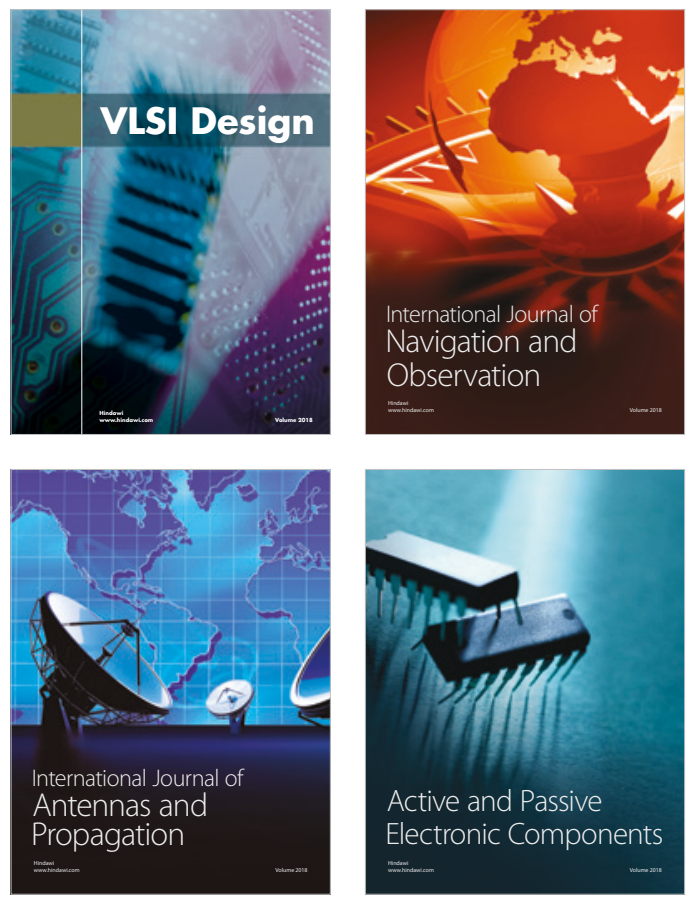
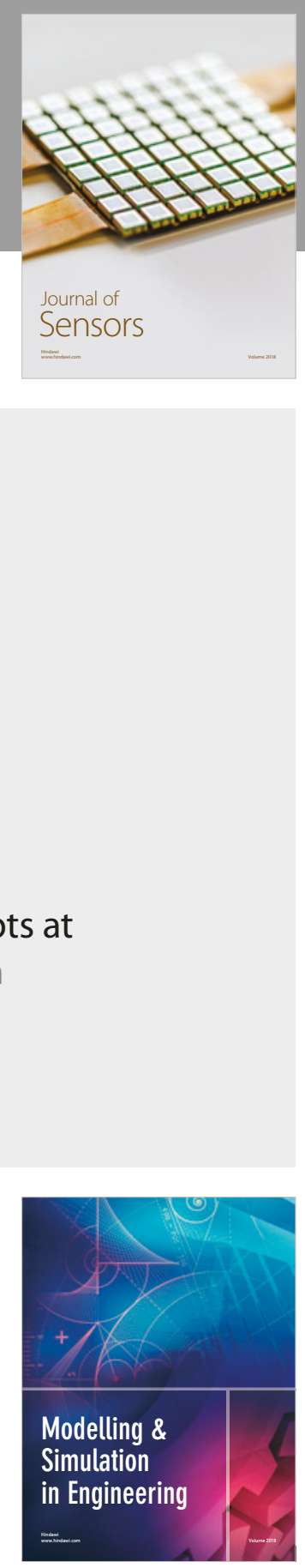

\section{Advances \\ Multimedia}
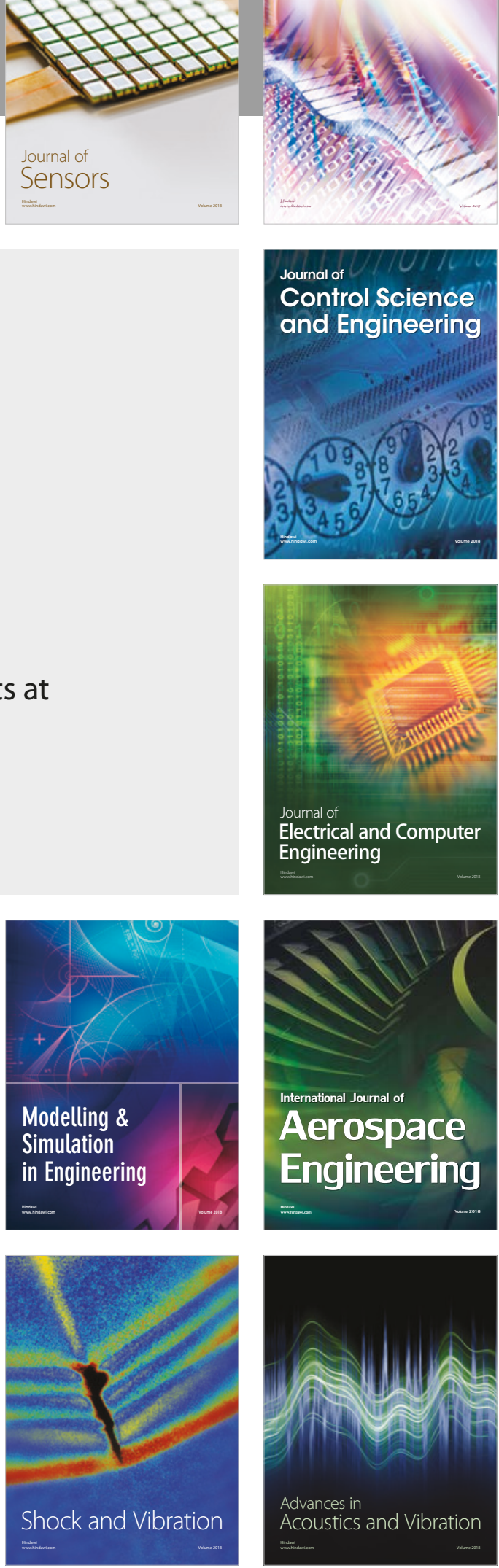